\title{
Assessing Surface Water Quality in the Serbian Part of the Tisa River Basin
}

\author{
Goran Babić1 ${ }^{1}$ Milovan Vuković ${ }^{1 *}$, Danijela Voza ${ }^{1}$, Ljiljana Takić ${ }^{2}$, \\ Ivana Mladenović-Ranisavljević \\ ${ }^{1}$ University of Belgrade, Technical Faculty (Department of Engineering Management), Bor, Serbia \\ ${ }^{2}$ University of Niš, Faculty of Technology, Leskovac, Serbia
}

Received: 14 July 2018

Accepted: 16 September 2018

\begin{abstract}
The aim of this study was to evaluate the quality of the Tisa River on its flow through Serbia. The water quality status and the spatial and temporal trends along the Tisa River were assessed through the application of ten SWQI parameters derived from a six-year public database of environmental data (2011-16). Also, the created data set was treated by multivariate techniques in order to identify the similiraties and differences between sampling periods and locations, recognize variables that affect the temporal and spatial water quality and present anthropogenic impact on water quality parameters. This study reveals that water quality along the Tisa River decreases slightly downstream. Obtained values of SWQI descriptive quality indicator indicated that water quality on this course, during the monitoring period, was good (72-83) and very good (84-89). Multivariate statistical techniques (PCA/FA) led to the conclusion that the changes in water quality mostly occur under the influence of organic pollutants (anthropogenic) and nutrients (total phosphorus, ammonia, etc.).
\end{abstract}

Keywords: Tisa River, water quality index, multivariate statistical techniques, principal component analysis (PCA), spatial similarities, temporal similarities

\section{Introduction}

Water quality has recently become a major issue in the management of international river basins, especially in Europe. The need for integrating the water quality issues in various environmental initiatives worldwide reflects the profound impact of economic, technological and demographic changes upon freshwater resources, including rivers [1-3]. One can say that water quality is one of the most important factors that have to be

*e-mail:mvukovic@tfbor.bg.ac.rs considered in order to evaluate the sustainability of a particular watershed [4]. Water quality is, in fact, one of the main characteristics of a river, even when its purpose is other than human water supply; for instance, tourism, transportation and consumption [5].

The quality of surface water bodies is a very sensitive environmental issue. Surface water quality is determined by natural processes - climatic, hydrological and geological (air temperature, precipitation, mean water level, flow variation, soil erosion and basin lithology) - as well as human activities such as urbanization, industry, mining, metallurgy, agriculture and increased consumption of freshwater resources [6-11]. For instance, untreated wastewater from mines 
and metallurgical facilities is one of reasons for high heavy metal load of river waters. Nutrients (nitrogen and phosphates) from agriculture represent a major part of diffuse water pollution [12, 13]. These factors, often acting as persistent sources of pollution, seriously degrade aquatic ecosystems, impairing the use of water for various activities (drinking, agriculture, industry and other purposes).

A number of techniques have been used in order to monitor and evaluate the effects of pollution on surface waters, including: traditional methods, modelling approaches, water quality indices (WPI [11]), WQII, WQI, for instance), multivariate statistical techniques (so-called chemometrics [14]), artificial neural networks, artificial intelligence, fuzzy logic, and also combinations of some of these [15]. These methods were developed under specific conditions and, therefore, there is a need to choose an optimal water quality assessment method for the specific purpose and particular watershed [16]. For instance, traditional methods cannot successfully examine the non-linearity, subjectivity and complexity of the cause-effect relationships between water quality variables and water quality status [17]. On the other hand, multivariate statistical techniques for the processing of large data sets have been applied to environmental systems during the last decades [18]. This paper presents an assessment of the water quality data using the water quality index (WQI) and various multidimensional analysis data methods such as principal component analysis, factor analysis and cluster analysis.
In this study, the quality of water in the Tisa River Basin (TRB) in Serbia was determined (Fig. 1 [19]). The Tisa is, like many other international rivers in developing countries, polluted mostly from anthropogenic sources, including agriculture, industry, sewer system, waste waters and water barrage systems [20]. Despite a number of studies, there is a lack of information on the concentrations and distributions of various pollutants in surface water of the Lower Tisa [21, 22]. In line with the recommendations of the European Water Framework Directive 2000/60/EC (WFD), this study explores the eco-chemical status (on the basis of physical-chemical parameters) of the Tisa River on its flow through Serbia, including the tributaries and the rest of its watershed in this country. This is in line with the so-called "catchment-based approach" proposed by EU/WFD that points out the involvement of various stakeholders in order to find out more cost-effective solutions for water quality problems [23].

\section{Material and Methods}

\section{Study Area}

The Tisa River Basin (TRB) is mainly located in the northeastern part of the Danube River Basin (DRB) $\left(801,500 \mathrm{~km}^{2}\right)$, the "most international" river basin in the world as it touches 19 countries and supports 30 different types of ecosystems [24, 25]. Although only $10 \%$ of the DRB belongs to Serbia, $92.3 \%$ of its

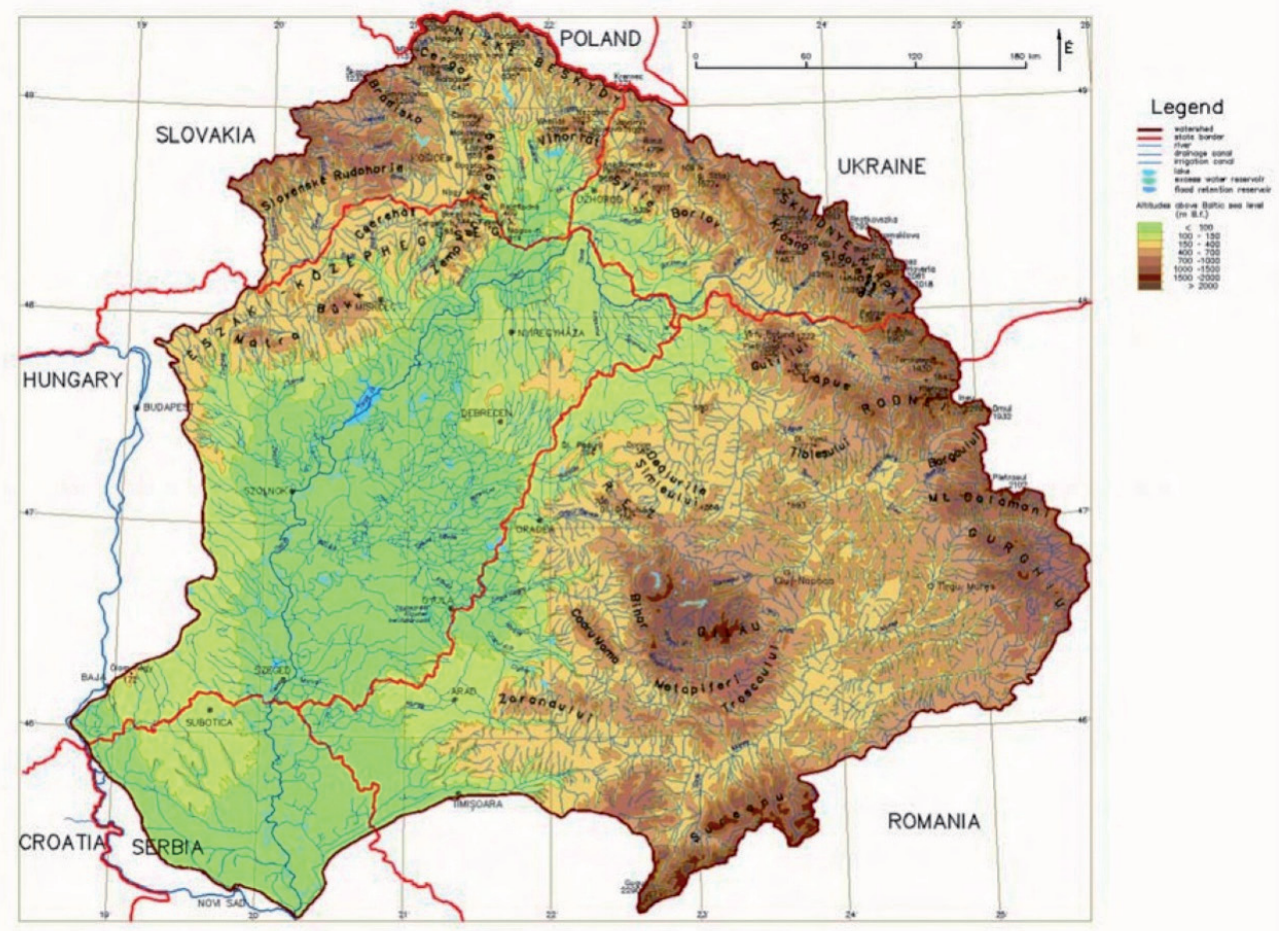

Fig. 1. Orography and river network of the Tisa River Basin. 
Table 1. Water bodies with associated label, type, and monitoring stations.

\begin{tabular}{|c|c|c|c|}
\hline Water body & Label & Type & Monitoring stations \\
\hline Tisa & TIS_1, TIS_2 & 1 & Martonoš (S1), Padej (S2), Bečej (S3), Žabalj (S4), Titel (S5) \\
\hline Zlatica & ZLA & 2 & Vrbica \\
\hline Stari Begej & STBEG & 1 & Hetin \\
\hline Krivaja & KRIV_1, KRIV_3 & 5 & Karađorđevo, Mali Iđoš, Srbobran \\
\hline Kereš & KER & 5 & Subotica \\
\hline
\end{tabular}

national territory is located within the DRB [26]. With a catchment area of $157,186 \mathrm{~km}^{2}$ [56], the TRB is the largest sub-basin of the DRB. It is interesting to mention that the proportion of surface water bodies classified as heavily modified water bodies (HMWBs) in the TRB is $34 \%$ - less than in the DRB (40\%) [27].

The larger part of this sub-basin (almost two thirds) consists of the mountainous catchments of the Tisa and the tributaries in Ukraine, Romania and the eastern part of Slovakia, while the remainder is the lowland area of the Pannonian Plain, mainly in Hungary and Serbia (Fig. 1). The TRB (home to approximately 14 million people) encompasses five countries: Ukraine $(8.1 \%$ of the total catchment area), Romania (42.6\%), Slovakia (9.7\%), Hungary (29.4\%) and the smallest share in Serbia $(6.6 \%)$. The Tisa River catchment area is asymmetrical: the left side covers $60 \%$ of the entire watershed area and the tributaries from this region influence the entire Tisa system [28].

The Tisa collects the waters of the Carpathian Basin's eastern region and the total length of its main branch nowadays is $964 \mathrm{~km}$ (in Serbia, $164 \mathrm{~km}$ ) [29]. Before the river regulation, the total length of the Tisa was $1,419 \mathrm{~km}$, which decreased to $966 \mathrm{~km}$ after regulation [30]. Currently, almost one third (32\%) of its length is strongly regulated [31]. Flowing from its spring in the Eastern Carpathians in Ukraine to its confluence with the Danube at Titel in Serbia, the Tisa represents a highly important ecosystem to all riparian countries. Its main tributaries are: Mures/Maros, Koros/Criş, Somes/ Szamos, Slana/Sajo and Bodrog (shared by Hungary, Slovakia and Ukraine). The Tisa can be divided into three distinct parts: (1) the Upper Tisa (upstream from the confluence of the Somes River); (2) the Middle Tisa (between the mouth of the Somes and the Mures Rivers); and (3) the Lower Tisa (downstream from the confluence of the Mures River). The Lower Tisa receives the water from Bega/Begej River and other tributaries indirectly via the Danube-Tisa-Danube Canal System. The Begej River originates from the Old Begej and the Begej Canal, both flowing from Romania to Serbia. The average amount of water brought by the Tisa into the Danube is 25.4 billion $\mathrm{m}^{3} \cdot \mathrm{year}^{-1}$ [32].

The Serbian part of the TRB covers almost half of Vojvodina (Northern Autonomous Province of Serbia). The Tisa River divides the province of Vojvodina into two regions: the Banat on the east and the Bačka region on the west. This Serbian province is part of a large flat depression of the Pannonian Basin. The Vojvodina region is the most important area of commercial agriculture as cropland occupies nearly four-fifths of its territory.

\section{Stations and Sampling Period}

The data sources used for water quality monitoring and determining ecological status of the Tisa River in Serbia were the Data Fund of the Republic Hydro meteorological Service of Serbia, as well as the Serbian Environmental Protection Agency (SEPA). The first institution provided data for 2011 and the second for the remaining years (2012-2016) [33]. The evaluation of water quality in the Serbian part of the TRB was conducted using the data set obtained from 11 hydrological measuring stations (Table 1).

Five stations, as can be seen in Fig. 2 [34], are located on the Tisa River: (1) Martonoš (S1) - the input profile $(155 \mathrm{~km}$ upstream from the confluence with the Danube), (2) Padej (S2, $105 \mathrm{~km})$, (3) Novi Bečej (S3, $65 \mathrm{~km})$, (4) Žabalj (S4, $37 \mathrm{~km})$ and (5) Titel (S5) - the output profile $(9 \mathrm{~km})$.

\section{Monitored Parameters}

Water quality parameters were measured at the 11 points on the courses of the Tisa River and its tributaries. The obtained values were used to calculate the Serbian water quality index (SWQI) an environmental indicator developed by the Serbian Environmental Protection Agency [35] and based on the Water Quality Index method developed in the United Kingdom [36]. SWQI consists of 10 quality parameters: temperature $(\mathrm{T})$, oxygen saturation, $\mathrm{pH}$, biochemical oxygen demand $\left(\mathrm{BOD}_{5}\right)$, ammonium $\left(\mathrm{NH}_{4}\right)$, total nitrogen oxides, orthophosphates $\left(\mathrm{PO}_{4}\right)$, suspended matter (SM), electrical conductivity (EC) and the most probable number of Escherichia coliform bacteria (E. coli/MPN).

Each of these selected parameters of water quality $\left(q_{\mathrm{i}}\right)$ does not have the same relative significance on the overall water quality assessment. Therefore, each parameter has a specific weight $\left(w_{\mathrm{i}}\right)$, according to its importance. The SWQI is obtained by summarizing the products of all quality parameters $\left(q_{\mathrm{i}}\right)$ and their 


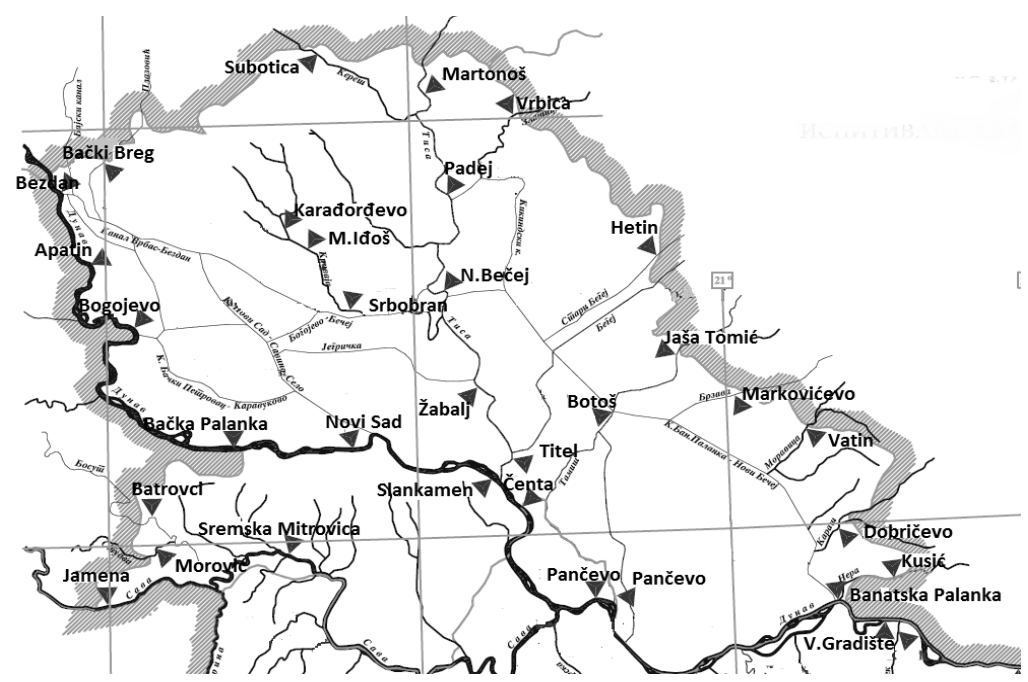

Fig. 2. Map of monitoring stations in the province of Vojvodina.

corresponding weights $\left(w_{\mathrm{i}}\right)$. By summing their products, the SWQI value of 100 is obtained as the ideal sum of all parameters. The maximum value of each parameter is shown in Table 2 [37].

The formula used for SWQI calculation is:

$\mathrm{SWQI}=0.18 \% \mathrm{O}_{2}+0.15 \mathrm{BPK}_{5}+0.12 \mathrm{NO}_{4}+0.09 \mathrm{pH}+$ $0.08 \mathrm{~N}+0.08 \mathrm{PO}_{4}+0.07 \mathrm{SM}+0.05 \mathrm{t}+0.06 \mu \mathrm{S}+0.12 \mathrm{MPN}$

Table 2. SWQI parameters and their corresponding maximum $q_{\mathrm{i}}$ $\mathrm{x} w_{\mathrm{i}}$ values [37].

\begin{tabular}{|c|c|}
\hline Parameter & Maximum $q_{\mathrm{i}} \mathrm{x} w_{\mathrm{i}}$ value \\
\hline Oxygen saturation & 18 \\
\hline BOD $_{5}$ & 15 \\
\hline Ammonium & 12 \\
\hline $\mathrm{pH}$ & 9 \\
\hline Total nitrogen oxides & 8 \\
\hline Orthophosphates & 8 \\
\hline Suspended solids & 7 \\
\hline Temperature & 5 \\
\hline Electrical conductivity & 6 \\
\hline$E$. coli & 12 \\
\hline SWQI $=\sum\left(q_{\mathrm{i}} \mathrm{x} w_{\mathrm{i}}\right)$ & 100 \\
\hline
\end{tabular}

If some measurements for particular parameters are missing, the value of arithmetically determined WQI is corrected by multiplying the index value by $1 / x$, where $x$ relates to the sum of arithmetically measured values of available parameters [38].

Based on the calculated values of SWQI, the water quality of analysed water body will be evaluated according to the classification criteria of the descriptive quality indicator given in Table 3 [35]. These descriptive criteria of water quality are presented on a national river map by corresponding colours. The main obstacle of the SWQI is a relatively small number of parameters. Although these parameters offer information about organic loading, they do not deal with heavy metal pollution [39].

\section{Statistical Analysis}

Many previously conducted studies have indicated that multivariate techniques help interpret extensive data sets, allowing for identification of sources of water pollution (point or non-point sources) and provide a powerful tool for reliable management of water resources [34, 40-49]. In this study, the multivariate data analysis was carried out using cluster analysis (CA), principal component analysis (PCA) and factor analysis (FA). All the statistical computations were made using the software package SPSS V. 17.0.

A widely used technique for pattern recognition is $\mathrm{CA}$, and we use it here to discover the intrinsic structure

Table 3. Classification of surface water by the SWQI method [35].

\begin{tabular}{|c|c|c|c|c|c|}
\hline Value & $100-90$ & $89-84$ & $83-72$ & $71-39$ & $38-0$ \\
\hline $\begin{array}{c}\text { Qualitative descrip- } \\
\text { tion }\end{array}$ & Excellent & Very good & Good & Poor & Very poor \\
\hline Color & Dark blue & Light blue & Green & Yellow & Red \\
\hline Class & & I & II & III & IV \\
\hline
\end{tabular}


of a data set without making "a priori assumptions about the data to classify the objects of the system into categories or clusters based on their nearness or similarity" [50]. The data set was treated by hierarchical clustering according to Ward's method of linkage with a square Euclidean distance as a measure of similarity $[42,50]$.

PCA provides information dealing with the most important parameters describing the entire data sets, allowing, at the same time, for data reduction with a minimum loss of original information. It is convenient to apply PCA/FA to the normalized data in order to make a comparison between patterns of the water sample chemical structure, as well as to identify factors that influence each other [42].

\section{Results and Discussion}

\section{Descriptive Statistics}

Maximum, minimum and average values of 10 water quality parameters for all five monitoring stations on the Tisa are presented in Table 4. Monthly

Table 4. Values of the water quality parameters along the Tisa for 2011.

\begin{tabular}{|c|c|c|c|c|c|c|c|}
\hline Parameter & Unit & & $\mathrm{S} 1$ & $\mathrm{~S} 2$ & $\mathrm{~S} 3$ & $\mathrm{~S} 4$ & S5 \\
\hline \multirow{3}{*}{ Temperature } & \multirow{3}{*}{${ }^{\circ} \mathrm{C}$} & $\min$. & 2.00 & 2.00 & 1.80 & 1.00 & 1.20 \\
\hline & & $\max$. & 25.8 & 25.40 & 25.50 & 24.50 & 25.00 \\
\hline & & median & 13.68 & 14.70 & 14.32 & 12.31 & 12.61 \\
\hline \multirow{3}{*}{$\mathrm{pH}$} & \multirow{3}{*}{ - } & $\min$. & 7.90 & 7.80 & 7.80 & 7.80 & 7.90 \\
\hline & & $\max$ & 8.40 & 8.30 & 8.20 & 8.20 & 8.30 \\
\hline & & median & 8.06 & 8.00 & 7.97 & 7.93 & 8.02 \\
\hline \multirow{3}{*}{ Oxygen saturation } & \multirow{3}{*}{$\%$} & $\min$. & 81 & 64 & 65 & 62 & 51 \\
\hline & & $\max$. & 114 & 99 & 95 & 93 & 93 \\
\hline & & median & 93.08 & 82.45 & 80.54 & 78.60 & 82.00 \\
\hline \multirow{3}{*}{ Electrical conductivity } & \multirow{3}{*}{$\mu \mathrm{S} / \mathrm{cm}$} & $\min$. & 343 & 378 & 375 & 330 & 329 \\
\hline & & $\max$. & 746 & 759 & 675 & 674 & 664 \\
\hline & & median & 530.25 & 543.45 & 530.09 & 543.00 & 543.70 \\
\hline \multirow{3}{*}{$\mathrm{BOD}_{5}$} & \multirow{3}{*}{$\mathrm{mg} / \mathrm{L}$} & $\min$. & 1.30 & 1.00 & 1.00 & 1.30 & 1.20 \\
\hline & & $\max$. & 3.60 & 3.10 & 2.60 & 2.40 & 3.60 \\
\hline & & median & 2.10 & 1.68 & 1.80 & 1.77 & 1.84 \\
\hline \multirow{3}{*}{ Suspended matter } & \multirow{3}{*}{$\mathrm{mg} / \mathrm{L}$} & $\min$. & 7 & 3 & 3 & 5 & 7 \\
\hline & & $\max$. & 225 & 100 & 100 & 76 & 65 \\
\hline & & median & 44.33 & 27.54 & 27.81 & 33.40 & 33.60 \\
\hline \multirow{3}{*}{ Total nitrogen oxides } & \multirow{3}{*}{$\mathrm{mg} / \mathrm{L}$} & $\min$. & 0.39 & 0.44 & 0.52 & 0.54 & 0.65 \\
\hline & & $\max$ & 1.59 & 1.63 & 1.21 & 1.41 & 1.38 \\
\hline & & median & 0.96 & 0.99 & 0.91 & 0.93 & 0.93 \\
\hline \multirow{3}{*}{ Orthophosphates } & \multirow{3}{*}{$\mathrm{mg} / \mathrm{L}$} & $\min$. & 0.003 & 0.011 & 0.027 & 0.045 & 0.038 \\
\hline & & $\max$ & 0.210 & 0.115 & 0.094 & 0.107 & 0.090 \\
\hline & & median & 0.049 & 0.058 & 0.061 & 0.069 & 0.062 \\
\hline \multirow{3}{*}{ Ammonium } & \multirow{3}{*}{$\mathrm{mg} / \mathrm{L}$} & $\min$. & 0.02 & 0.02 & 0.02 & 0.02 & 0.02 \\
\hline & & $\max$ & 0.23 & 0.17 & 0.21 & 0.21 & 0.27 \\
\hline & & median & 0.08 & 0.08 & 0.10 & 0.11 & 0.10 \\
\hline \multirow{3}{*}{ E. coli } & \multirow{3}{*}{ Count/100 ml } & $\min$. & 220 & 500 & 220 & 220 & 220 \\
\hline & & $\max$ & 24000 & 3800 & 7500 & 880 & 500 \\
\hline & & median & 4491.43 & 1575.00 & 3405.00 & 440.00 & 406.67 \\
\hline
\end{tabular}


Table 5. Water quality characterized by the maximum concentration level (MCL) in Serbia [15].

\begin{tabular}{|c|c|c|c|c|}
\hline Parameter (unit) & MCL class I & MCL class II & MCL class III & MCL class IV \\
\hline Temperature $\left({ }^{\circ} \mathrm{C}\right)$ & - & - & - & - \\
\hline $\mathrm{pH}$ & $6.8-8.5$ & $6.8-8.5$ & $6-9$ & $6-9$ \\
\hline Oxygen saturation $(\%)$ & $90-105$ & $70-90$ & $50-75$ & $30-50$ \\
\hline Electrical conductivity $(\mu \mathrm{S} / \mathrm{cm})$ & - & - & - & - \\
\hline BOD $_{5}(\mathrm{mg} / \mathrm{l})$ & 2 & 4 & 7 & 20 \\
\hline Suspended matter $(\mathrm{mg} / \mathrm{L})$ & 10 & 30 & 80 & 100 \\
\hline Total nitrogen oxides $(\mathrm{mg} / \mathrm{L})$ & 10 & 10 & 15 & 15 \\
\hline Orthophosphates $(\mathrm{mg} / \mathrm{L})$ & 0.005 & 0.005 & 0.01 & 0.01 \\
\hline Ammonium $(\mathrm{mg} / \mathrm{L})$ & 0.1 & 0.1 & 0.5 & 0.5 \\
\hline$E$. coli $($ count $/ 100 \mathrm{ml})$ & 200 & 10000 & 20000 & 20000 \\
\hline
\end{tabular}

values of these parameters were used to calculate SWQI. According to water regulations in Serbia [15], all surface water bodies in this country are divided into four classes. Maximum concentration level (MCL) is defined for each of these classes (Table 5).

The temperature of the Tisa varies from $1.0^{\circ} \mathrm{C}$ to $25.8^{\circ} \mathrm{C}$ during the year. This result indicates the absence of extreme variations as a condition for maintaining water life. The Tisa has $\mathrm{pH}$ values in the range of 7.80 and 8.40 , which is common for rivers. Maximum values were recorded in different months: May (stations S1 and S2), November (S3 and S4) and June (S5). The water acidity $(\mathrm{pH})$ defines solubility and biological availability of different chemical compounds of nitrogen, phosphorus, carbon and heavy metals. The average $\mathrm{pH}$ value indicates a certain level of organic pollution of the water, but still within the limits of good eco-chemical status $-\mathrm{pH}<8.5$ (class I).

The average values for electrical conductivity, ranging from $759 \mu \mathrm{S} / \mathrm{cm}$ (Padej, S2) to $329 \mu \mathrm{S} / \mathrm{cm}$ (Žabalj, S4), are below the limiting value $(<1000)$ as defined by the Council Directive 75/440/EEC [51]. In terms of suspended solids (matter), small variations have been detected among average values, ranging from $27.54 \mathrm{mg} / \mathrm{L}$ (S2) to $44.33 \mathrm{mg} / \mathrm{L}$ (S1); thus, according to this quality criterion, the Tisa River belong to class II. Electrical conductivity and suspended solids are highly dependent on hydrological conditions, such as flow rate and water level, or current seasonal conditions, such as rainy and dry periods. Many of these factors have an influence on lower values of electrical conductivity of the Tisa. Average oxygen saturation (93.08\%) was within the highest rank (class 1) only in the case of entry profile (Martonoš, S1); while the others belonged to class II. Also, both the maximum and minimum values of oxygen saturation decreased downstream - from Martonoš (S1) to Titel (2) - even below $70 \%$. This is a clear sign of possible pollution; in fact, the eutrophic tendencies are responsible for decreased oxygen saturation. In the TRB, eutrophication is one of the problems that threatens not only the biodiversity and the economic potential of this riverine ecosystem, but also the Danube delta and the Black Sea [52, 53]. Therefore, ecosystem services of the Tisa should not be neglected in management and planning [54-56].

The results of $\mathrm{BOD}_{5}$ values detected at the monitoring station Martonoš (S1) indicate the presence of biodegradable organic mater $\left(2.1 \mathrm{mgO}_{2} / \mathrm{L}\right)$ and classify the water as class II, while the values at remaining stations (in the range of 1.68 and 1.84) indicate a decreasing trend of biological consumption of oxygen and an improvement of water quality level. The total nitrogen oxides and orthophosphates, as an indicator of pollution by chemical industry, are correlated and show a slight deviation from class II. On the other hand, ammonium ion strongly deviated from the limiting value $(0.05 \mathrm{mg} / \mathrm{L})$. Finally, the presence of Escherichia coliform bacteria is an indicator of the highest sanitary contamination of water at Martonoš station (S1), but the values are significantly lower toward the confluence of the Tisa with the Danube.

Previously conducted investigations indicated that the concentrations of various pollutants (in particular, heavy metals) were very high in surface water and sediments of the Upper and Middle Tisa because of metallic wastewater discharges from various miningmetallurgical facilities operating there. Nevertheless, a decrease in the concentrations of nutrients such as nitrogen and phosphorus in water and the sediments of the river were reported [57]. In Hungary, for instance, the total consumption of commercial fertilisers (during the period 1988-1993) dropped from 617,000 to 124,000 tonnes per year [58]. Although agriculture plays a dominating role in the Hungarian part of the TRB, the observed positive shift in water quality (frequently reported) was probably caused by changes in agricultural practices. It should also be mentioned 
that all the large watercourses in this part of Europe exhibited a downward trend of organic matter content in the period 1991-2006; the Tisa's average level of $\mathrm{BOD}_{5}$ was between 3 to $5 \mathrm{mg} / \mathrm{L}$ [59]. In fact, biological oxygen demand (BOD) in rivers is the only water quality indicator that every EU member state is obliged to monitor on a regular basis [60].

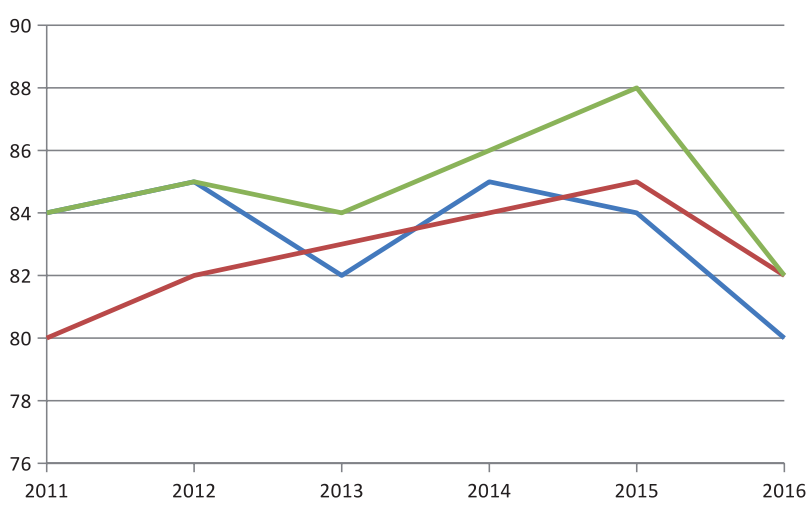

Fig. 3. Annual and seasonal values of SWQI for Martonoš station; blue, red and green lines denote cold, warm and annual periods, respectively.

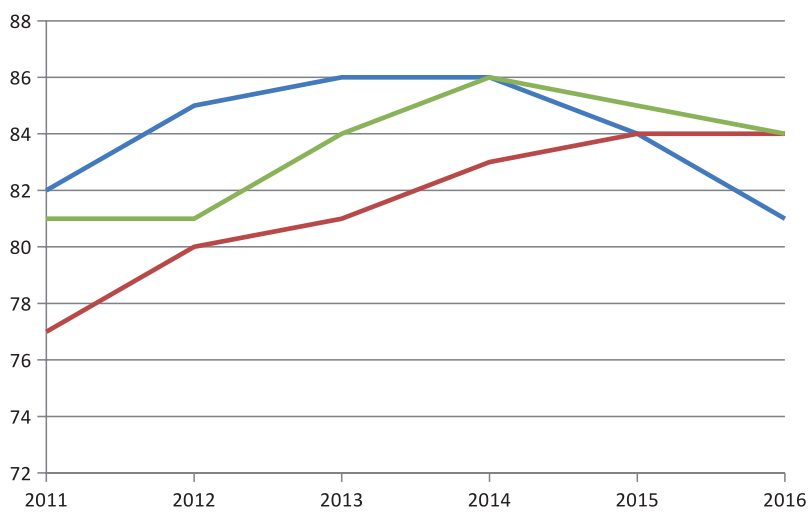

Fig. 4. Annual and seasonal values of SWQI for Novi Bečej station; blue, red and green lines denote cold, warm and annual periods, respectively.

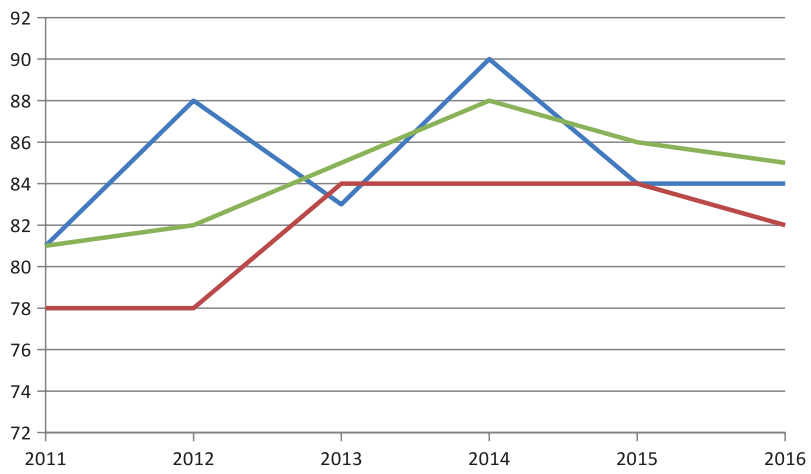

Fig. 5. Annual and seasonal values of SWQI Titel station; blue, red and green lines denote cold, warm and annual periods, respectively.

\section{Water Quality Index}

Average values of 10 water quality for the three control points on the Tisa (Martonoš, Novi Bečej and Titel) were determined and, consequently, monthly values of these parameters were used in order to calculate SWQI for the Tisa. SWQI was calculated 72 times throughout six years and these values are indicated in Figs 3-5 for the cold period (blue line), warm period (red line) and whole year (green).

SWQI values for Martonoš station (Table 3), calculated on an annual basis, ranged from 82 in 2016 to 88 in 2015. According to obtained results, water quality of the Tisa at Martonoš might be mainly classified as very good (84-89). However, insight into the seasonal changes reveals a quite different picture. It is noticeable that during the warm period water quality at Martonoš station decreases, and it could be classified as good (72-83). A similar change was noticed at two remaining stations: Novi Bečej and Titel (Figs 4 and 5). The last station on the Tisa (before its flow into the Danube), Titel, is very interesting. On this station, for the first time during the research period, we obtained values (90), according to which water quality could be classified as excellent in 2014.

Values of SWQI for the research period (2011-2016) also are presented for all three monitoring stations (Fig. 6). As can be seen, the highest average values were recorded at the Titel (in 2014) and Martonoš (2015) profiles (both 88). The lowest average SWQI values were obtained in the first year (2011) of the investigated period. At Novi Bečej station, the SWQI of 81 was obtained in two consecutive years (2011 and 2012).

The spatial and temporal variations of surface water quality along the Tisa were assessed according to the SWQI methodology based on six-year public base of environmental data. In the case of the Tisa, this method is used as a general descriptive index to determine the overall water quality. Namely, seasonal variations of water quality were observed and some patterns were

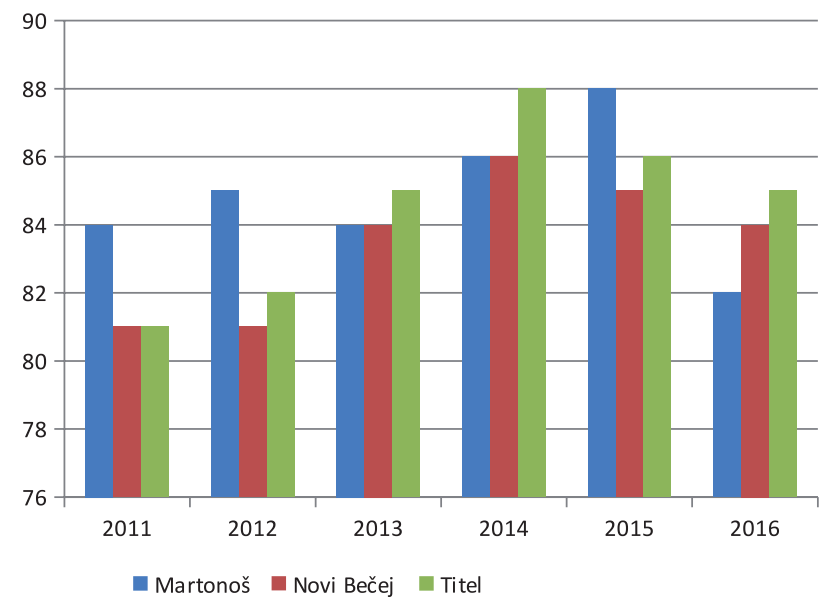

Fig. 6. Annual average SWQI scores for stations on the Tisa River. 


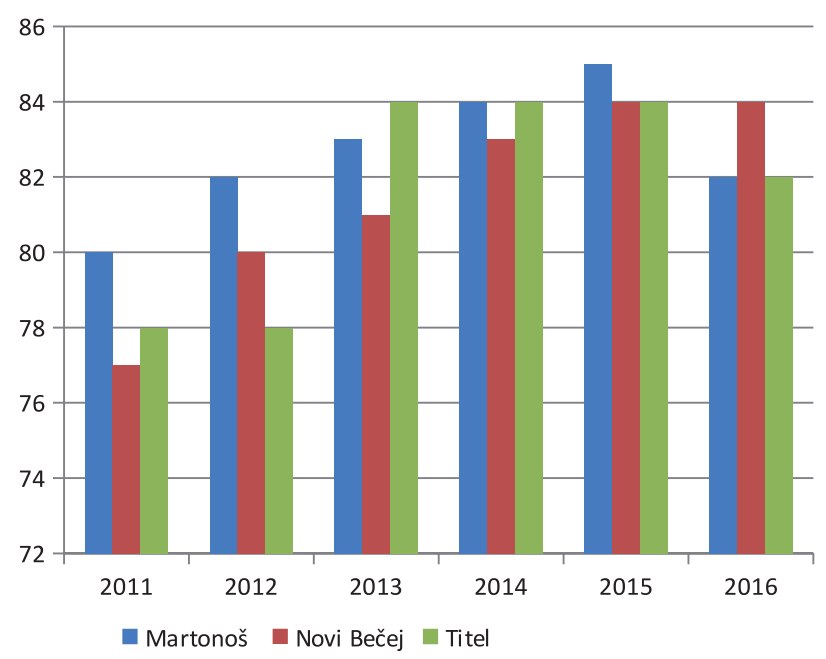

Fig. 7. Average SWQI scores for stations on the Tisa River obtained for the warm period.

recognized on all three stations. The lowest values of SWQI, not surprisingly, were observed at all stations (Martonoš, Novi Bečej and Titel) during the warm period: especially, in June, July, August and September (Fig. 7). During the summer months, increased biological activity causes a considerable decrease in concentration of dissolved oxygen.

On the basis of annual values of SWQI presented in Figs. 3-7, one can claim that water quality of the Tisa is worse in warmer periods of the year. The same trend has been shown in other similar studies [39, 41, 46]. Finally, according to obtained SWQI values on the Tisa, one can assume that the lowest water quality is recorded at Novi Bečej station. In other words, water quality along the Tisa decreases downstream in the investigated period.

\section{Cluster Analysis}

In this study, surface water quality was not assessed only for the main course of the Tisa, but for the entire TRB in Serbia (Table 1, Fig. 2). In order to determine the similarity groups of sampling stations, cluster analysis was carried out. A dendrogram (Fig. 8) was obtained as a result, according to which 11 monitoring stations are grouped into two statistically significant clusters in a distinct connection $\left(\mathrm{D}_{\text {link }} / \mathrm{D}_{\text {max }}\right) \times 100$.

Cluster 1 consists of eight sampling stations in the Serbian part of the TRB (Martonoš, Novi Bečej, Titel, Sombor, Melenci, Bački Breg 1, Bačko Gradište, Srpski Itebej; Fig. 2), while cluster 2 includes the three remaining sampling stations (Vrbica, Bački Breg 2, Hetin). Part of cluster 1 are three stations on the Tisa, previously described (Figs 3-7). Cluster 1 corresponds to low-contaminated sites and Cluster 2 corresponds to high-contaminated sites. Cluster 2 sites (Vrbica and Hetin) were situated downstream of the miningmetallurgical facilities in Romania, and these sites were polluted with wastewater discharge.

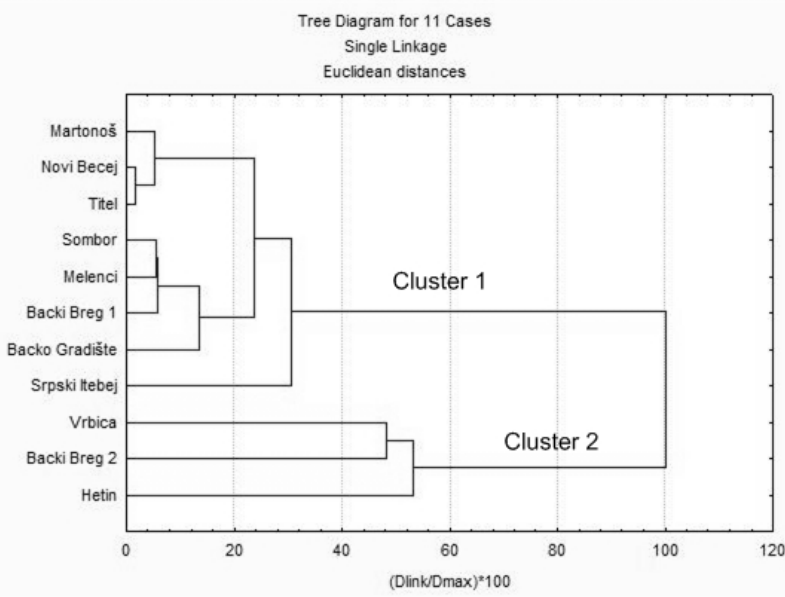

Fig. 8. Dendrogram showing hierarchical clustering of sampling stations on the Tisa River Basin in Serbia.

Locations within the same cluster have similar characteristics and common sources of pollution. Consequently, sometimes it is only one monitoring station from each cluster, and it can be used as a reliable indicator of the water quality of the whole group. In a word, cluster analysis allows for rapid water quality assessment.

\section{Principal Component Analysis/Factor Analysis}

The results obtained by PCA/FA analysis for two seasonal periods (cold and warm) for the investigated period (2011-2016) are presented in Table 6. Four principal components were obtained with eigenvalues higher than 1, explaining almost $67 \%$ of the total variance in the water data sets for the cold months. The factor loadings were classified as "strong", "moderate" and "weak", corresponding to absolute loading values of $>0.75,0.75-0.50$ and $0.50-0.30$, respectively [40].

The first principal component (PC1), which accounts for $22.01 \%$ of the total variance, has a strong positive loading on nitrates and total nitrogen as well. On the other hand, there is a weak negative loading on temperature. In the second PC (PC2), which accounts for $19.02 \%$ of the total variance, it can be noticed that there moderate positive loadings on nitrates and ammonium and weak positive loading on $\mathrm{BPK}_{5}$. PC3 (13.52\% of the total variance) has strong positive loading on dissolved oxygen and moderate positive loadings on $\mathrm{pH}$ and $\mathrm{BPK}_{5}$. Finally, the last principal component (PC4), which participates with $12.67 \%$ of the total variance, is characterized by a weak negative loading on suspended solids (SM) and moderate positive loadings on electrical conductivity and orthophosphates. It is reasonable to assume that PC2 is connected with anthropogenic pollution sources originating from the consumption of fertilizers in agricultural activities [61].

A quite different combination of principal components was obtained when the data sets for the warm period were processed. Here, four principal 
Table 6. Loadings of variables (10) on significant principal components (with Varimax rotation) for cold and warm seasons.

\begin{tabular}{|c|c|c|c|c|}
\hline \multicolumn{5}{|c|}{ Cold season } \\
\hline & \multicolumn{4}{|c|}{ Component } \\
\hline & 1 & 2 & 3 & 4 \\
\hline Temperature & -0.414 & -0.160 & 0.223 & 0.025 \\
\hline Suspended solids & 0.127 & 0.335 & -0.096 & -0.594 \\
\hline Dissolved oxygen & 0.119 & -0.141 & 0.823 & -0.278 \\
\hline $\mathrm{pH}$ & 0.132 & -0.251 & 0.775 & 0.269 \\
\hline Electrical conductivity & 0.195 & 0.047 & 0.045 & 0.767 \\
\hline Ammonium & 0.007 & 0.822 & -0.199 & 0.066 \\
\hline Nitrites & 0.104 & 0.770 & -0.047 & -0.005 \\
\hline Nitrates & 0.948 & -0.036 & 0.171 & 0.109 \\
\hline Total oxidized nitrogen & 0.949 & -0.022 & 0.171 & 0.110 \\
\hline Orthophosphates & 0.080 & 0.309 & -0.145 & 0.663 \\
\hline $\mathrm{BPK}_{5}$ & -0.175 & 0.544 & 0.617 & 0.059 \\
\hline \multicolumn{5}{|c|}{ Warm season } \\
\hline & \multicolumn{4}{|c|}{ Component } \\
\hline & 1 & 2 & 3 & 4 \\
\hline Temperature & -0.744 & -0.231 & 0.035 & -0.079 \\
\hline Suspended solids & 0.112 & -0.149 & 0.354 & -0.066 \\
\hline Dissolved oxygen & 0.084 & -0.541 & -0.045 & 0.729 \\
\hline $\mathrm{pH}$ & 0.073 & 0.069 & -0.237 & 0.873 \\
\hline Electrical conductivity & 0.026 & 0.902 & -0.164 & 0.089 \\
\hline Ammonium & -0.024 & 0.133 & 0.796 & -0.155 \\
\hline Nitrites & 0.140 & -0.161 & 0.811 & 0.123 \\
\hline Nitrates & 0.902 & -0.256 & 0.164 & -0.050 \\
\hline Total oxidized nitrogen & 0.897 & -0.259 & 0.193 & -0.045 \\
\hline Orthophosphates & -0.179 & 0.843 & -0.033 & -0.073 \\
\hline $\mathrm{BPK}_{5}$ & -0.309 & 0.249 & 0.373 & 0.575 \\
\hline
\end{tabular}

${ }^{*}$ Bold and italic values indicate strong and middle loadings, respectively

components account for almost $72 \%$ of the total variance in the water data sets for the summer months. The first principal component (PC1), which accounts for $26.80 \%$ of the total variance, has a strong positive loading on nitrates and total nitrogen, just like during the cold period. However, instead of weak negative loading on temperature in the cold period, a moderate loading on this parameter is obtained for the warm period. In the second PC, which accounts for $16.89 \%$ of the total variance, there are strong positive loadings on electrical conductivity and orthophosphates and weak positive loading on dissolved oxygen. PC3 (14.71\% of the total variance) has strong positive loadings on ammonium and nitrites. The last component (PC4), which takes part with $13.23 \%$ of the total variance, is characterized by strong positive loading on $\mathrm{pH}$, moderate positive loading on dissolved oxygen and weak positive loading on $\mathrm{BPK}_{5}$.

The analysis of presented results shows noticeably higher water quality level at the exit profile as opposed to the entry profile of the Tisa into Serbia. This is a consequence of long-term anthropogenic influences on the Tisa in the vicinity of Martonoš. For instance, water quality of this river during the period 1991-2000 was never classified as class I; it was always between classes II and III [62]. Yet this watercourse remains as a highly impaired water body, and, consequently, the single-factor assessment method used in this study is appropriate. Namely, this assessment method is applicable to conditions when a single water quality parameter impairs water quality much more seriously than others [63]. Therefore, eco-chemical status of the Tisa is threatened mostly by: (1) relatively small concentrations of dissolved oxygen (especially, during the warm period); (2) high values of $\mathrm{BOD}_{5}$; (3) huge amounts of coliform bacteria; (4) high contents of suspended matter; and (5) large amounts of nutrients (total $\mathrm{P}$, ammonia, etc.). Moreover, long-term negative environmental changes in the TRB during the last 150 years have led to an increasing frequency of extreme events, such as severe floods (the most recent in the period from 1998 to 2006), periods of drought (particularly in Hungary and Serbia), as well as landslides and erosion in the uplands (in Ukraine and Romania) [27, 63].

The results obtained by the single-factor assessment method correspond to those obtained by the SWQI method and multivariate techniques that were used for the evaluation of the surface water quality of the Tisa. The SWQI method is suitable when a specific pollution factor plays a dominant impairment role while PCA analysis is appropriate to apply when the relationships among water quality parameters are linear [64, 65]. However, some PCA limitations remain; for instance, this technique ignores the degree of data dispersion and it cannot reasonably process the nonlinear data. In this study, consequently, the SWQI index was chosen as the best choice for evaluating the water quality conditions of the heavily polluted Tisa.

The results presented in this study show that the Tisa differs significantly from the Danube and, consequently, it might impair the eco-chemical status of the most international river in Europe. On its flow through Serbia, the Danube is joined by two of its largest tributaries the Sava (by volume) and the Tisa (by length) - making its volume more than doubled. It is not so common that one large international river has a sharp increase in volume due to the inflow of its tributaries at relatively small territory. Hence, these large tributaries in the middle section of the Danube course may influence its eco-chemical status. The discharge of the Tisa at its mouth equals $25 \%$ of the discharge of the Danube. It was shown, for instance, that the Tisa might be responsible for the lowering $\mathrm{BOD}_{5}$ and $\mathrm{pH}$ values of the Danube 
and for increasing the phosphates concentration [66]. Compared to the Danube, the Tisa had elevated values of COD, suspended matter, total dissolved solids, total phosphorus, phosphates and ammonia.

Fortunately, much of negative influence of the Tisa pollution load, related to intensive agricultural production, is neutralized by dilution and the selfpurification processes in the Danube. At the first sampling station after the mouth of the Tisa, located $50 \mathrm{~km}$ downstream, significant influence on the majority of water quality parameters was not detected. However, this does not mean that a serious threat from the Tisa to the eco-chemical status of the Danube is completely removed. It originates from the influx of the nutrients (total phosphorus, ammonia, etc.). Unlike some other pollutants that can be neutralized, nutrients remain in the environment even when they are adsorbed by biota [66].

The Tisa course in Serbia is under substantial influence of the agricultural pollution since it flows through the Pannonian Plain. The Tisa flows through the Serbian province of Vojvodina, where agricultural land covers more than $80 \%$ of the watershed area, the average total nitrogen concentrations during the last decades exceeded $5 \mathrm{mg} / \mathrm{L}$. Therefore, it is required to reduce the volume of intensified agricultural acitivity or to introduce so-called "precision farming" [56]. On the basis of results obtained by cluster analysis, it can be concluded that more attention has to be paid to small watercourse (tributaries) draining into the Serbian part of the Tisa River Basin.

Obviously, the entire sub-basin is highly vulnerable to heavy metal pollution due to urbanization, industrialization and various irrigation projects such as the well-known Hydro-system Danube-Tisa-Danube (HsDTD) - the biggest canal network in the DRB and a significant source of indirect pollution of the Tisa [67]. On the other hand, the HsDTD, primarily constructed to provide drainage and water for irrigation, represents a habitat for aquatic organisms, including significant fish populations $[68,69]$.

As a signatory party of the Danube River Protection Convention and a contracting party of the International Commission for the Protection of the Danube River (ICPDR), since August 2003, Serbia has been committed to implementing the Danube Convention. Some of the objectives of these documents relate to the control of hazardous substances originating from accidents and the implementation of measures to reduce pollution loads that inflow into the Black Sea from the DRB. Since ICPDR got the mandate for implementation of the European Union (EU) Water Framework Directive (WFD), Serbia, although not yet an EU member state, has been undertaking measures to contribute to fulfilment of the WFD main objective: the protection and improvement of the status for all European water bodies to the level of "good ecological and chemical status" [70, 71].

\section{Conclusions}

This study confirms the importance of applying a WQI as a useful tool for representing information on surface water quality. It reflects the overall influence of various sources and allows for easy interpretation of data obtained from monitoring stations. This study indicates that water quality along the Tisa (on its course through Serbia) decreases significantly during the warm period, but it still provides desirable values that, according to SWQI descriptive quality indicator, have been determined as good (72-83) and very good (84-89). Based on the presented results that were derived from the analysis of the impact of 10 parameters measured on three points during the years 2011-2016 on water quality of the Tisa, it might be concluded that anthropogenic factors (mostly agricultural pollution) significantly affect changes in water quality throughout the considered period.

The anthropogenic impact on the quality of this watercourse is confirmed by using the multivariate statistical methods: cluster analysis, principal component analysis and factor analysis. Application of these techniques helps identify and locate pollution sources and gain insight into the temporal and spatial changes of surface water quality.

The results obtained by PCA/FA clearly reveal that the variations of water quality mainly occur under the influence of soluble salts (natural) and organic pollutants and nutrients (anthropogenic). The results of PCA analysis also confirm that 10 chosen variables (originated from the SWQI indicator) are still required due to the fact that accounts for $70 \%$ of the total variance of the data.

\section{Acknowledgements}

Prepared as a part of project No. OI 179013 as supported by the Ministry of Education, Science and Technological Development of the Republic of Serbia.

\section{Conflict of Interest}

The authors declare no conflict of interest.

\section{References}

1. SHMUELI D.F. Water quality in international river basins. Political Geography. 18, 437, 1999.

2. KOWALKOWSKI T., ZBYTNIEWSKI R., SZPEJNA J., BUSZEWSKI B. Application of chemometrics in river water classification. Water Research. 40 (4), 744, 2006.

3. O'CONNELL E. Towards adaptation of water resource systems to climatic and socio-economic change. Water Resources Management. 31, 2965, 2017. 
4. CÓRDOBA E.B., MARTÍNEZ A.C., FERRER E.V. Water quality indicators: Comparison of a probabilistic index and a general quality index. The case of the Confederacíon Hidrográfica del Júcar (Spain). Ecological Indicators. 10 (5), 1049, 2010.

5. AREERACHAKUL S. Comparison of ANFIS and ANN for estimation of biochemical oxygen demand parameter in surface water. International Journal of Chemical and Biological Engineering. 6, 286, 2012.

6. SIMEONOV V., STRATIS J.A., SAMARA C., ZACHARIADIS G., VOUTSA D., ANTHEMIDIS A., SOFONIOU M., KOUIMTZIS TH. Assessment of the surface water quality in Northern Greece. Water Research. 37, 4119, 2003.

7. SHRESTHA S., KAZAMA F. Assessment of surface water quality using multivariate statistical techniques: A case study of the Fuji river basin, Japan. Environmental Modelling and Sowtware. 22 (4), 464, 2007.

8. PRATHUMRATANA L., STHIANNOPKAO S., WOONG KIM K. The relationship of climatic and hydrological parameters to surface water quality in the lower Mekong River. Environment International. 34, 860, 2008.

9. DRAGIĆEVIĆ S., NENADOVIĆ S., JOVANOVIĆ B., MILANOVIĆ M., NOVKOVIĆ I., PAVLOVIĆ D., LJEŠEVIĆ M. Degradation of Topčiderska River water quality (Belgrade). Carpathian Journal of Earth and Environmental Sciences. 5 (2), 177, 2010.

10. NĘDZAREK A., BONISŁAWSKA M., TÓRZ A., GAJEK A., SOCHA M., HARASIMIUK F.B. Water Quality in the Central Reach of the Ina River (Western Pomerania, Poland). Polish Journal of Environmental Studies. 24 (1), 207, 2015.

11. TAKIĆ LJ., MLADENOVIĆ-RANISAVLJEVIĆ I., VASOVIĆ D., ĐORĐEVIĆ LJ. The assessment of the Danube River water pollution in Serbia. Water Air and Soil Pollution. 228, 2017.

12. GURZAU A.E., POPOVICI E., PINTEA A., POPA O., POP C., DUMITRASCU I. Quality of surface water sources from a central Transylvanian area as a possible problem for human security and public health. Carpathian Journal of Earth and Environmental Sciences. 5 (2), 2119, 2010.

13. ZHANG S., GAO P., TONG Y., NORSE D., LU Y., POWLSON, D. Overcoming nitrogen fertilizer over-use through technical and advisory approaches: A case study from Shaanxi Province northwest China. Agriculture. Ecosystems and Environment. 209, 89, 2015.

14. MENDIGUCHIA C., MORENO C., GALINDO-RIAÑO M.D., GARCIA-VARGAS M. Using chemometric tools to assess anthropogenic effects in river water, a case study: Guadalquivir River (Spain). Analytica Chimica Acta. 515, 143, 2004.

15. WALKER D., JAKOVLJEVIĆ D., SAVIĆ D., RADOVANOVIĆ M. Multi-criterion water quality analysis of the Danube River in Serbia: A visualisation approach. Water Research. 79, 158, 2015.

16. JI X., DAHLGREN R.A., ZHANG M. Comparison of seven water quality assessment methods for the characterization and management of highly impaired river systems. Environmental Monitoring and Assessment. 188 (1), 14, 2016.

17. YAN H., ZOU Z., WANG H. Adaptive neuro fuzzy inference system for classification of water quality status. Journal of Environmental Sciences. 22 (12), 1891, 2010.

18. OKETOLA A.A., ADEKOLUREJO S.M., OSIBANJO O. Water quality assessment of River Ogun using multivariate statistical techniques. Journal of Environmental Protection. 4, 466, 2013.

19. ICPDR. Sub-Basin Level Flood Action Plan Tisza River Basin. Flood Protection Expert Group. 2009.

20. TANOS P., KOVÁCS J., KOVÁCS S., ANDA A., HATVANI I.G. Optimization of the monitoring network on the River Tisza (Central Europe, Hungary) using combined cluster and discriminant analysis, taking seasonality into account. Environmental Monitoring and Assessment. 187, 575, 2015.

21. MILANOVIĆ A., MILIJAŠEVIĆ D., BRANKOV J. Assessment of polluting effects and surface water quality using water pollution index: a case study of Hydro-system Danube-Tisa-Danube, Serbia. Carpathian Journal of Earth and Environmental Sciences. 6, 269, 2011.

22. JOSIMOV DUNĐERSKI J., SAVIĆ R., GRABIĆ J., BLAGOJEVIĆ B. Water quality trends of the Tisa River along its flow through Serbia. Annual Set The Environment Protection Rocznik Ochrona Środowiska. 19, 17, 2017.

23. RILEY C., TYSON J.M. Europe's Water Framework Directive: Discovering hidden benefits. Water Science and Technology. 53 (10), 269, 2006.

24. KIRSCHNER A.K.T., KAVKA G.G., VELIMIROV B.,MACH R.L., SOMMER R., FARNLEITNER A.H. Microbiological water quality along the Danube River: Integrating data from two whole-river surveys and a transnational monitoring network. Water Research. 4 (3), 3673, 2009.

25. ICPDR. The Danube River Basin facts and figures. International Commission for the Protection of the Danube River [online]. [Access 24.02.2015]. http://www.icpdr.org/ main/danube basin/river-basin, 2015.

26. LÁSZLÓFFY. A Tisza, vízi munkálatok és vízgazdálkodás a tiszai vízrendszerben [in Hungarian]. (Works on the River Tisza and water management on the Tisza's water system). Budapest: Akadémiai Kiadó. 1982.

27. VAN NOOD M., KOVÁCS P., WHALLEY P., HEILMANN D., MILOVANOVIĆ M., KUNIKOVA E., GRAZIELLA J., IAROCHEVITCH A. Integrated Tisza River Basin Management Plan. Water Research and Management. 1 (2), 1, 2011.

28. ANDÓ M., VÁGÁS I. The catastrophic flood in 1970 along the Valley of Tisza River. Földrajzi Közlemények. 96 (1), 18, 1972 [in Hungarian].

29. SAKAN S., GRŽETIĆ I., ĐORĐEVIĆ D. Distribution and fractionation of heavy metals in the Tisa (Tisza) River sediments. Environmental Science and Pollution Research. 14 (4), 229, 2007.

30. NÁDUDVARI A., CZAJKA A. Statistical calculations of the Tisza River Channel changes along Vezsney and Martfü (Hungary) from 1873-2010. Carpathian Journal of Earth and Environmental Sciences. 9 (2), 57, 2014.

31. MARTIGNAGO G. A comparative analysis of Sava, Tisza, Dniester transborder water river basin management agreements and cooperation policies and their impact on the enhancing of mutual understanding and the well-being of people involved ( $\mathrm{PhD}$ dissertation). 2017.

32. PÉCSI M. A tiszai Alföld [in Hungarian]. Budapest: Akadémiai Kiadó. 1969.

33. RHMSS. Hydrological yearbook-surface waters, 2011. Republic Hydrometeorological Service of Serbia. [Access 24.02.2015]. http://www.hidmet.gov.rs/ciril/hidrologija/ povrsinske_godisnjaci.php, 2012.

34. VUJOVIĆ S.R., KOLAKOVIĆ S.R., BEČELIĆ-TOMIN M.R. Evaluation of heavily modified water bodies in 
Vojvodina by using multivariate statistical techniques. Chemical Industry. 67 (5), 823, 2013.

35. SEPA. Serbian Environmental Protection Agency. The Ministry of Environment and Planning. http://www.sepa. gov.rs. 2010.

36. SDD. Development of Water Quality Index. The Scottish Development Department. Engineering Division. Edinburgh. UK. 1976.

37. VELJKOVIĆ N., LEKIĆ D., JOVIČIĆ M., PAJČIN N. Internet application Serbian Water Quality Index. Water Sanitary Engineering. 40 (3), 15, 2010 [In Serbian].

38. WRC. Water Research Centre. B.F. Environmental Consultants Inc. May 2011. http://water-research.net/ watrqualindex/index.htm, 2011.

39. BJELAJAC D., LEŠČEŠEN I., MICIĆ T., PANTELIĆ M. Estimation of water quality of Sava River (Vojvodina, Serbia) in the period 2004-2011 using Serbian Water Quality Index (SWQI). Geographica Pannonica. 17 (4), 91, 2013.

40. LIU C.W., LIN K.H., KUO Y.M. Application of factor analysis in the assessment of groundwater quality in a Blackfoot disease are in Taiwan. Science of the Total Environment. 313, 77, 2003.

41. SINGH K.P., MALIK A., MOHAN D., SINHA S. Multivariate statistical techniques for the evaluation of spatial and temporal variations in water quality of Gomti River (India) - A case study. Water Research. 38, 3980, 2004.

42. ISCEN F.C., EMIROGLY Ö., ILHAN S., ARSLAN N., YILMAZ V, AHISKA S. Application of multivariate techniques in the assessment of surface water quality in Ulabat Lake, Turkey. Environmental Monitoring and Assessment. 144, 269, 2008.

43. LIAO S.W., GAU H.S., LAI W.L., CHEN J.J., LEE C.G. Identification of pollution of Tapeng Lagoon from neighbouring rivers using multivariate statistical method. Journal of Environmental Management. 88, 286, 2008.

44. VAROL M., GÖKOT B., BEKLYEN A., ŞEN B. Water quality assessment and apportionment of pollution sources of Tigris river (Turkey) using multivariate statistical techniques - A case study. River Research and Applications, 28, 1428, 2012.

45. HAMCHEVICI C., UDREA I. Improving the sampling strategy of the Joint Danube Survey 3 (2013) by means of multivariate statistical techniques applied on selected physico-chemical and biological data. Environmental Monitoring and Assessment. 185, 9495, 2013.

46. VOZA D., VUKOVIĆ M., NIKOLIĆ Đ., TAKIĆ LJ. Application of multivariate statistical techniques in the water assessment of the Danube River, Serbia. Archives of Environmental Protection. 41 (4), 96, 2015.

47. TOKATLI C. Assessment of water quality in the Meriç River as an ecosystem element in Turkey's Thrace Region. Polish Journal of Environmental Studies. 24 (5), 2205, 2015.

48. HUA A.K., KUSIN F.M., PRAVEENA S.M. Spatial variation assessment of river water quality using environmetric techniques. Polish Journal of Environmental Studies. 25 (6), 2411, 2016.

49. UNCUMUSAOĞLU A.A., AKKAN T. Assessment of water quality of Yağlidere Stream (Turkey) using multivariate statistical techniques. Polish Journal of Environmental Studies. 26 (4), 1715, 2017.

50. VAROL M., ŞEN B. Assessment of nutrient and heavy metal contamination in surface water and sediments of the upper Tigris River, Turkey. Catena. 92, 1, 2012.
51. EEC. Council Directive 75/440/EEC of 16 June 1975 concerning the quality required of surface water intended for the abstraction of drinking water in Member States, OJ No 1. 194, 25/7/1975, 26-31, May 2011.

52. BABOVIĆ N., MARKOVIĆ DEJAN, DIMITRIJEVIĆ V., MARKOVIĆ DRAGAN. Some indicators of water quality of the Tamiš River. Chemical Industry \& Chemical Engineering Quarterly. 17 (1), 107, 2011.

53. MÖLDER A., SCHNEIDER E. On the beautiful diverse Danube? Danubian floodplain forest vegetation and flora under the influence of river eutrophication. River Research and Applications. 27, 881, 2011.

54. DE GROOT R. Function-analysis and valuation as a tool to assess land use conflicts in planning for sustainable, multi-functional landscapes. Landscape and Urban Planning. 75 (3-4), 175-186, 2006.

55. PETZ K., MINCA E.L., WERNERS S.E., LEEMANS R. Managing the current and future supply of ecosystem services in the Hungarian and Romanian Tisza River Basin. Regional Environmental Change. 12, 689, 2012.

56. MATYSIK M., ABSALON D., RUMAN M. Surface Water Quality in Relation to Land Cover in Agricultural Catchments (Liswarta River Basin Case Study). Polish Journal of Environmental Studies. 24 (1), 175, 2015.

57. GRIMVALL A., PER STÅLNACKE P., TONDERSKI A. Time scales of nutrient losses from land to sea - a European perspective. Ecological Indicators. 14, 363, 2000.

58. OLÁH, J., OLÁH, M. Improving landscape nitrogen metabolism in the Hungarian lowlands. Ambio. 25, 331, 1996.

59. DIMKIĆ M.A., MILOVANOVIĆ M., DIMKIĆ D. Sustainable and adaptive water management: Case study of water management in Serbia. Water Research and Management. 1 (4), 9, 2011.

60. ŠILJIĆ TOMIĆ A.N., ANTANASIJEVIĆ D.Z., RISTIĆ M.Đ., PERIĆ-GRUJIĆ A.A., POCAJT V.V. Modelling the BOD of Danube River in Serbia using spatial, temporal, and input variables optimized artificial neural network models. Environmental Monitoring and Assessment. 188 (5), 300, 2016.

61. VEGA M., PARDO R., BARRADO E., DEBAN L. Assessment of seasonal and polluting effects on the quality of river water by exploratory data analysis. Water Research. 32, 3581, 1998.

62. PAVIĆ D., MESAROŠ M., ŽIVKOVIĆ N. Water pollution and water quality of the River Tisa in Serbia. Collection of the Papers. 58, 47, 2010.

63. HEILMANN D., FEHÉR J. Strengthening cooperation between river basin management planning and risk prevention to enhance the status of the water of the Tisza River Basin (JOINTISZA). Hungarian Journal of Hydrology. 97 (3), 35, 2017.

64. XIALIANG J., DAHLGREN R.A., ZHANG M. Comparison of seven water quality assessment methods for the characterization and management of highly impaired river systems. Environmental Monitoring and Assessment. 188, 15, 2016.

65. BABIC G. Monitoring the quality of surface water using SWQI method. [In:] Đukić A. (Ed.). Water $2018-47^{\text {th }}$ Annual Conference of the Serbian Water Pollution Control Society (Conference Proceedings). Sokobanja, 12.-14. June, 185, 2018 [In Serbian].

66. ILIJEVIĆ K., OBRADOVIĆ M., JEVREMOVIĆ V., GRŽETIĆ I. Statistical analysis of the influence of major tributaries to the eco-chemical status of the Danube 
River. Environmental Monitoring and Assessment. 187, $553,2015$.

67. TEODOROVIĆ I. Ecotoxicological research and related legislation in Serbia. Environmental Science and Pollution Research. 16 (Suppl 1), S123, 2009.

68. PANTELIĆ M., ĐURĐEV B., STANKOV U., DRAGIĆEVIĆ V., DOLINAJ D. Water quality as an indicator of local residents' attitudes towards tourism development: A case study of settlements along Veliki Bački Kanal, Vojvodina, Serbia. Knowledge and Management of Aquatic Ecosystems. 404, 09, 2012.

69. GRABIĆ, J., BENKA, P., BEZDAN, A., JOSIMOVDUNĐERSKI, J., SALVAI, A. Water quality management for preserving fish populations within hydro-system Danube-Tisa-Danube, Serbia. Carpathian Journal of Earth and Environmental Sciences. 11 (1), 235, 2016.

70. RICHTER S., VÖLKER J., BORCHARDT D., MOHAUPT V. The Water Framework Directive as an approach for Integrated Water Resources Management: Results from the experiences in Germany on implementation, and future perspectives. Environmental Earth Science. 69, 719, 2013.

71. MAIA R. The WFD implementation in the European member states. Water Resources Management. 31, 3043, 2017. 